\title{
The political development in Sri Lanka after civil war ended: a critical review for after Zarb-e-Azb operation in Pakistan
}

\author{
Taha Shabbir ${ }^{*}$, Kehkashan Naz ${ }^{2}$ \\ ${ }^{1,2}$ Federal Urdu University of Arts, Science and Technology, Karachi, Sindh, Pakistan \\ *e-mail: tahashabbir51@gmail.com
}

\begin{abstract}
The Sri Lankan civil war began in 1983 and lasted until 2009. The tension stems from Sri Lanka's colonial period and subsequent postcolonial policies that harmed the Tamil people. Without viable alternatives, a part of the Tamil population resorted to the degree of brutality that precipitated a second civil war. Regional, domestic, and global attempts to bring the war to a halt have been futile, though some more local measures have been active. A ruthless military campaign brought the conflict to an end. However, nothing has been done in the aftermath of the war to try to resolve the civil war, including its roots. Sri Lanka's civil war exemplifies the uncertain existence of civil war resolution. With this in mind, the war's conclusion was unquestionably the product of a strategic triumph. However, the civil war should have ended; a unique constellation of structural, state, and national forces collaborated to allow for unrestricted military aggression. As long as the dominant forces, including the United States and significant European countries, understood that enough bloodshed had happened, the country's aggression could be brought to a stop. China and India, with India abstaining, voted to support the Sri Lankan government in its major offensive against insurgents. Internationally, the newly restored government used the full might of the forces against the rebels. As a consequence, those variables are deemed unusable in other situations. Tamil-Sinhala rivalry stretches all the way back to Sri Lanka's colonial period. The Tamil community took advantage of numerous market opportunities under British rule, which lasted from 1815 to 1948.
\end{abstract}

Keywords:

Civil war, peace and conflict, reconstruction, Zarb e Azb

\section{INTRODUCTION}

Sri Lanka's civil war started in 1983 and continued until 2009. The origins of the conflict can be traced back to Sri Lanka's colonial era and subsequent post-colonial policies that harmed the Tamil population. A segment of the Tamil community saw no feasible alternative and turned to the level of violence that precipitated a second civil war. Regional, international, and foreign efforts to halt the fighting were unsuccessful, although some more local initiatives were effective. The war was brought to an end by a brutal offensive policy. However, little steps have been taken in the war's aftermath to attempt to settle the civil war, especially its origins.

Sri Lanka's civil war demonstrates the precarious nature of resolving civil wars. With this in view, the war's end was a clear result of a military victory. However, it was possible to end the civil war; a unique constellation of powers at the structural, state, and national levels collaborated to allow unrestrained military violence. As the major powers, including the United States and important European countries, recognized that enough brutality has occurred, the country's violence could be halted. The People's Republic of China and India, while India abstained, voted to assist the Sri Lankan government as it conducted a massive offensive against the insurgents. Internationally, the government that recently regained independence used the full strength of its military against the insurgents. As a result, certain variables are impossible to exist in other contexts.

The conflict between Tamils and Sinhalese dates all the way back to Sri Lanka's colonial era. Under British rule, which lasted from 1815 to 1948 , the Tamil community took advantage of various business opportunities. Additionally, many community participants received their education in colonial countries due to a lack of opportunities in their home countries. However, with the exception of a handful, the Sinhalese society retained its alienation from the British. As could be anticipated, after Sri Lanka achieved independence in 1948, the proportion of Tamils employed in the civil service, academia, and law increased significantly. Historically, the Sinhalese community, which has worked with the British to effect a change in dominance since the 1930s, has been reluctant to embrace pluralism. When the compulsory adult franchise was extended to all Sri Lankans in 1931, no provisions for minority rights were created. Members of both the Tamil and Muslim communities expressed frustration in the inconsistency with which their interests are enforced. T displeased with the political trends, and many Tamils boycotted the elections held under this text. The 1947 Soulbury Constitution obliterated even instant liberty. However, the contention that no one could be discriminated against on the basis of ethnicity or religion proved to be a constitutional impediment. Finally, it formed a unitary and majoritarian state in practice. 
The First Sri Lankan Civil War raged in Colombo from 1983 to 1991. This initial phase of the war concluded with the invasion of India by India in 1987. After the second round of consultations, the informal talks between the Liberation Tigers of Tamil Eelam (LTTE) and President Chandrika Kumar's government came to an end in 1990. Finally, the agreement came to an end with the demise of the third phase in 2006. Following the second process, which resulted in the LTTE's death, the fourth step began and lasted until 2009, when the LTTE was finally defeated.

A laser-focused and unwavering initiative, supported by regional and international efforts, brought an end to the conflict. The offensive against the Liberation Tigers (LT) initiated by the Sri Lankan armed forces was motivated by the movement and occurred at a time when global support for allying with terror was at an all-time low. In general, the US and the European Union did little to rein in the Sri Lankan government. The People's Republic of China, as well as provincial governments, vehemently supported the dictatorship. One would expect the Indian government to exercise caution, but India did not. Sri Lankan forces' military victory over the LTTE is decisive. Total destruction of the adversary is a viable strategy for a war. There is no doubt, if any, that the LTTE has been annihilated. As previously reported, various international, domestic, and regional forces banded together to aid in the LTTE's military defeat. The most important of these factors to remember was the government's readiness to resist opposition.

Throughout the civil war against the LT and Sri Lanka, there was widespread unity and enthusiasm among the government's Sinhalese. The Rajapaksa government was widely criticized after the civil war, but suffered an unexpected defeat in 2015. Mithra Sirisai, the famous front-opposition candidate, received 51.3 percent of the vote. Rajapak's Tamil ethnic popularity has become a weakness for the Sinhalese citizens after systematic corruption and nepotism allegations. With the LTTE's demise and the establishment of a new regime, much of the injustices they perpetrated prior to the civil war remain unaddressed to this day. The new government is to be commended for establishing a new Department of National Reconciliation, which would concentrate on releasing captives and reclaiming residential property from captured military areas. The office has completed a portion of this work. The Terrorism Prevention Act empowers the government to arrest and imprison terrorists. Numerous militants have been arrested and remain imprisoned through the passage of several years.

The Tamil Diaspora is perpetually dissatisfied with Maithripala Sirisena's new government. Despite his willingness to understand the diaspora's needs, it is unclear if he will be effective in implementing such a strategy in his nation. Additionally, we must overcome certain significant socioeconomic forces and institutional impediments. Naturally, Buddhist monks, who continue to play a critical role in Sri Lanka's administration, lack empathy for Tamils. Among the societal impediments to stability are the uniformed services. The exemption was a significant factor in the region's militarization during this civil war, especially under President Rajapaksa's leadership. It will be impossible to limit the military's size and scope. With the current state of affairs, it's difficult to imagine how a new, more radical Tamil movement might thrive. There are no efforts to address the human and material implications of the civil war, which seem to be deepening the country's ethnic divisions. According to Fukuoma, a state's authority is not contingent on a common national origin. Numerous Tamils feel disconnected from Sri Lanka's state.

While the civil war has finished, the overall condition in Sri Lanka has just recently begun to change. A sizable number of Tamils have not returned to their homeland. The severity of enforced disappearances and torture has risen in the decline in the amount of political and human rights abuses. Additionally, the Sri Lankan government surveys and monitors persons associated with the LTTE on a regular basis. The military retains roles in the bulk of Sri Lanka's Tamil districts, but in smaller numbers than prior to the civil war. The government's Prevention of Terrorism Act (PTA) is predominately anti-Tamil. Indirectly, the Sri Lankan government is increasing the Tamil population's democratic disenfranchisement. For example, the Tamil community has found it more difficult to retain their Sinhalese language due to "Sinhalaization." In Tamil regions, Sinhalese temples, road signs, cities, villages, and Buddhist monuments gained prominence. These efforts also obliterated the Tamil perspective on Sri Lankan history and culture.

Prior to devolution, a race may have been a source of contention, but it was not the source of contention. The next time could be different. Since the civil war ended, the government has become a source of frustration for Tamils as well. The government's post-civil war actions have been more draconian against Tamils and Sinhalese, respectively. The administration's unprecedented use of exceptional political power in response to Black Lives Matter protests was the latest example of its willingness to strike against public will. The Sri Lankan government began rising during the civil war, a conflict sparked by the island's centuries-old British imperial presence. For many years, the government has proceeded to increase its influence. Finally, what this means for Sri Lanka's future is unknown. And even though the nation's ethnic wounds from the Sri Lankan civil war and political divisions can be repaired, the nation will still face more significant issues relating to its history and leadership. However, secure citizenship will act as a formidable check on a government's may power. Island unification can very well be the key to a more prosperous future. Sri Lanka is currently one of the most famous Asian tourist destinations. Sri Lanka's tourism sector has soared since the war ended. Additionally, it is regarded as a stable nation conducive to foreign sports. Sri Lanka and India co-hosted the cricket world cup in 2011. To summarize, Sri Lanka finally achieves stability and prosperity after decades of unrest and civil wars.

Pakistan's military had been preparing for the campaign for months, and the government had mobilized for a threepronged operation: isolating targeted insurgent factions, securing help from political parties, and protecting people from the operation's retaliation. Khawaja Asif, the country's defense minister, stated that the nation stood by its military: "The move was made after the failure of the dialogue plan. The operation will proceed until its logical conclusion is reached. Any organization that violates Pakistan's constitution, targets citizens, troops, and government facilities, or uses Pakistani territories to plot terrorist attacks will be targeted "'. Asif added that the federal and Khyber Pakhtunkhwa governments will support internally displaced persons: "We would work to ensure that the displaced do not have to remain away from their homes for an extended period." Fighting forces surrounded rebel bases in Mirali and Miranshah. Pakistani officials 
said that the Afghan National Security Forces (ANSF) were tasked with sealing their side of the border in order to prevent insurgents from escaping. The Air Force, Navy artillery, tanks, and land forces were all participating in the action. According to a military release, "on the behest of the army, Pakistan's armed forces have launched a robust campaign against international and domestic terrorists hidden in North Waziristan's sanctuaries." According to a military official, the military usually stationed between 14,000 and 20,000 soldiers in North Waziristan prior to the campaign, and he estimated the offensive to take no more than 30,000 troops in total.

Pakistani Prime Minister Nawaz Sharif declared peace talks with the Taliban after his inauguration, despite prior efforts to engage the Tehrik-i-Taliban Pakistan (TTP) in dialogue failing. The first round of talks between governmentappointed committees and the Taliban took place on 26 March 2014 at Islamabad's Khyber Pakhtunkhwa House. The Taliban did not appoint leaders from their ranks, instead choosing to present their opinions by pro-Taliban religious figures. The terrorists requested the adoption of Sharia in Pakistan; the Pakistani government demanded an end to war and insisted on negotiations taking place within the context of the Pakistani constitution. On 1 March 2014, a month-long truce was declared. Apart from meetings at Khyber Pakhtunkhwa House, talks included government officials traveling by helicopter to areas controlled by militants along the Pakistan-Afghanistan border. The government had suggested that if the talks collapsed, stronger military steps would be taken.

Negotiations broke down after the Taliban's execution of 23 Pakistani Frontier Corps soldiers on 17 February 2014. The rebels had captured the troops since 2010, and the TTP officially terminated the truce on 17 April 2014. Since March 2014, Taliban infighting has claimed the lives of more than 90 insurgents. Conflict between the Mehsud party (led by Sheheryar Mehsud) and another TTP contingent (led by Khan Said Sajna) hampered the negotiations. The talks became irreversibly harmed when the Taliban took responsibility for a terrorist assault on Karachi Airport that killed 28 civilians (including security personnel). "The army is prepared for an operation," a Pakistani military official was quoted as saying.

To determine the actual role played by government of Pakistan and Srilanka as the peace building initiative after remaining several years in war zones. The aim is to determine the government efforts in all domains of their responsibility: Setting up an Administrative Infrastructure, Refugee Crisis, Consolidation, Defense, Foreign Affairs, Economic Development, Framing a peace and other functions. This research proposes research questions as follows:

- Was Military action responsible for warranted end-of-year-long war in the country?

- Was Military operation responsible for alienating peace in Pakistan?

- Did Military operation bring considerable peace in the region?

\section{METHOD}

A content analysis research method has been used. Interviews were conducted with Pakistani as well as foreigners especially about the restoration of peace. Interviews collected data, and most of the research was library-based.

The method consists of design, procedure, and data analysis.

\section{RESULTS AND DISCUSSION}

\subsection{Srilankan Civil War}

Sri Lankan forces tried to reclaim areas occupied by the Liberation Tigers of Tamil Eelam (LTTE) (see Figure 1). The Liberation Tigers of Tamil Eelam's tactics against Government powers culminated in their designation as a terrorist organization in 32 countries, including the United States, India, Canada, and the European Union member states. Additionally, the Sri Lankan government powers have been accused of human rights violations, systemic immunity for grave human rights violations, a lack of regard for habeas corpus in illegal detentions, and forcible disappearances.

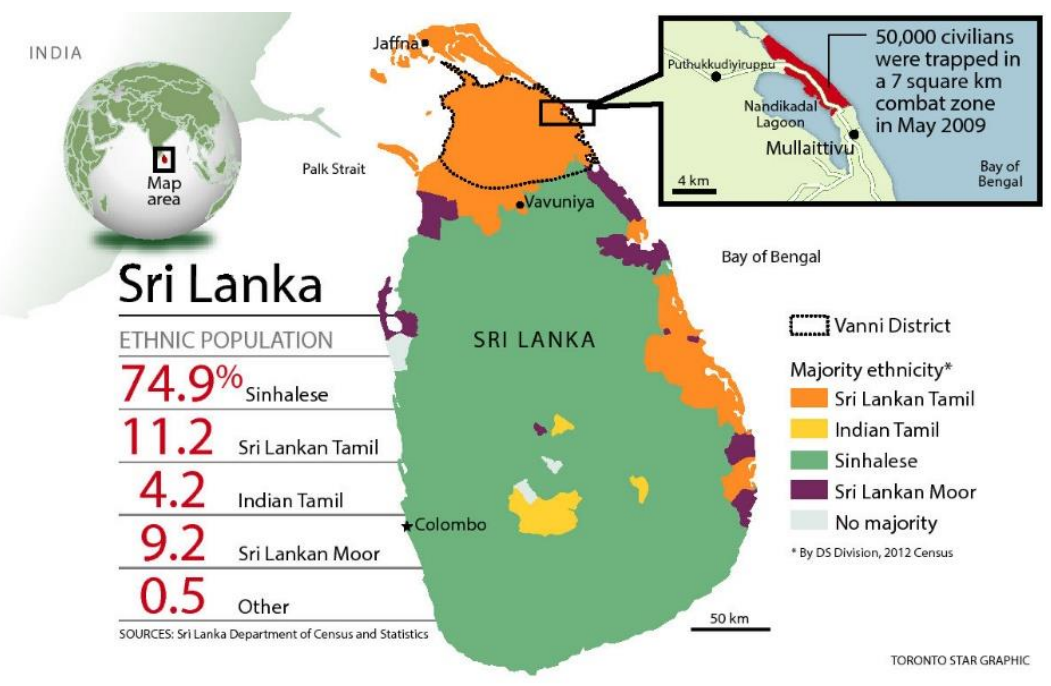

Figure 1. Tamil zone where war lasted 
After two decades of war and four unsuccessful peace negotiations, including the deployment of the Indian Army's Indian Peace Keeping Force from 1987 to 1990, a permanent diplomatic solution to the conflict became likely when a cease-fire was proclaimed in December 2001 and a ceasefire deal was concluded with international mediation in 2002. However, small hostilities resumed in late 2005, and the dispute escalated before the government conducted a series of massive military offensives against the LTTE starting in July 2006, successfully forcing the LTTE out of the island's entire Eastern province. The LTTE then announced that they will "resume their fight for independence and statehood."

In 2007, the government moved its offensive to the north of the region, and on 2 January 2008, it officially declared its withdrawal from the ceasefire arrangement, claiming that the LTTE had breached it over 10,000 times. Since then, the government has taken control of the whole area formerly controlled by the Tamil Tigers, including their de facto capital Kilinochchi, main military base Mullaitivu, and the entire A9 highway, aided by the destruction of a number of large arms smuggling vessels belonging to the LTTE and an international crackdown on funding for the Tamil Tigers. Following the loss of the LTTE, the pro-LTTE Tamil National Alliance abandoned calls for a separate state in favor of a federal solution. In May 2010, Mahinda Rajapaksa, Sri Lanka's then-president, named the Lessons Learnt and Reconciliation Commission (LLRC) to assess the dispute between the 2002 ceasefire resolution and the LTTE's loss in 2009.

At the conclusion of the civil war, the Sri Lankan state has faced widespread international condemnation for human rights violations including bombing civilian targets, the use of heavy weapons, kidnapping and massacres of Sri Lankan Tamils, and sexual harassment. The LTTE acquired prominence for committing multiple attacks against civilians of all ethnic groups, including those of Sinhalese and Sri Lankan Muslim origin, assassinating officials, and mainly targeting military targets with suicide bombings. The Metropolitan Police prosecuted British soldiers who worked for private military contractor Keenie Meenie Services, which educated the Sri Lankan police's Special Task Force, for war crimes. Remembrance Day and Mullivaikkal Remembrance Day commemorate the conclusion of the war and its casualties.

After two decades of violence and four failed peace talks, including the deployment of the Indian Army's Indian Peace Keeping Force from 1987 to 1990, a lasting political settlement to the conflict became possible when a cease-fire was declared in December 2001 and a cease-fire agreement was reached by international mediation in 2002. However, smallscale warfare resumed in late 2005, and the conflict intensified before the government launched a series of major military offensives against the LTTE beginning in July 2006, successfully driving the LTTE out of the entire Eastern province of the island. The LTTE then declared their intention to "resume their struggle for freedom and statehood."

In 2007, the government shifted its offensive to the region's north, and on 2 January 2008, it announced its withdrawal from the ceasefire agreement, saying the LTTE had violated it about 10,000 times. Since then, the government has seized possession of the whole territory formerly occupied by the Tamil Tigers, including their de facto capital Kilinochchi, their primary military base Mullaitivu, and the entire A9 highway, helped by the loss of a range of major weapons smuggling vessels belonging to the LTTE and a foreign crackdown on funding for the Tamil Tigers. Following the LTTE's defeat, the pro-LTTE Tamil National Alliance shifted away from demands for a separate state in favour of a federal solution. In May 2010, Sri Lanka's then-President Mahinda Rajapaksa formed the Lessons Learnt and Reconciliation Commission (LLRC) to investigate the conflict between the 2002 ceasefire agreement and the LTTE's defeat in 2009.

\subsection{Zarb-e-Azb and Its Consequences}

The military authorized the staggered repatriation of IDPs on 8 December 2014. Pakistan's army chief said that his primary objective was to expedite the return of IDPs. According to senior military leaders, civilian authorities have been ordered to coordinate the return of IDPs to areas cleared of terrorism. The repatriation process began on 31 March 2015. 219 IDPs from 62 families left Bannu on the first day for Spinwam and Shahmeri in North Waziristan. Around 1,200 families were to return to their homes in Sinwam, Shamiri, Mirali, and Bubali areas of NWA during the first process, which lasted until 24 April. Each family received Rs 25000 (US\$160) in cash assistance and Rs10000 (US\$62) to cover transportation costs to and from Mirzail. Each household will also receive a six-month food ration and non-food products. To ensure good vaccination prevention, children under the age of five were given anti-polio vaccinations and children under the age of ten were given anti-measles vaccines. As of 4 May 2015, only 230 displaced families had been repatriated since the program's inception. "If the region is de-listed as a war zone, the civil administration will return the entire displaced community within a month," an official in charge of IDP repatriation said. According to official reports, the deadline for IDPs to return was December 2016.

Zarb-e-Azb was a coordinated military operation launched by Pakistan's Armed Forces against a variety of terrorist organizations, including the Tehrik-i-Taliban Pakistan (TTP), the Islamic Movement of Uzbekistan, the East Turkestan Islamic Movement, Lashkar-e-Jhangvi, al-Qaeda, Jundallah, and the Haqqani network. The operation began on 15 June 2014 in North Waziristan, along the Pakistan-Afghanistan frontier, as part of a renewed attempt to combat militancy in the aftermath of the TTP and IMU-claimed assault on Karachi's Jinnah International Airport on 8 June. As of 14 July 2014, the operation had forcibly displaced approximately 929,859 civilians from North Waziristan's 80,302 households. Zarb-e-Azb, identified as a "comprehensive campaign" to root out both foreign and local insurgents hidden in North Waziristan, included up to 30,000 Pakistani soldiers. Pakistan's political, defense, and civilian sectors have all lent their support to the operation. As a result, Pakistan's overall security environment has changed, and militant threats have decreased to a six-year low not seen since 2008. Following Zarb-e-Azb, Operation Radd-ul-Fasaad launched in February 2017 in response to resurgence in terrorist incidents.

\subsubsection{Years after Pakistani military operation}

Six years after the Pakistani military conducted Operation Zarb-e-Azb in North Waziristan to destroy the Tehrik-i-Taliban Pakistan (TTP), local resident's report that the mountainous area of northwest Pakistan remains in ruins. Frustration with 
Pakistan's government and military, which seem to have deserted residents of North Waziristan following their liberation from the TTP and its international allies such as al-Qaida in June 2014, continues to rise.

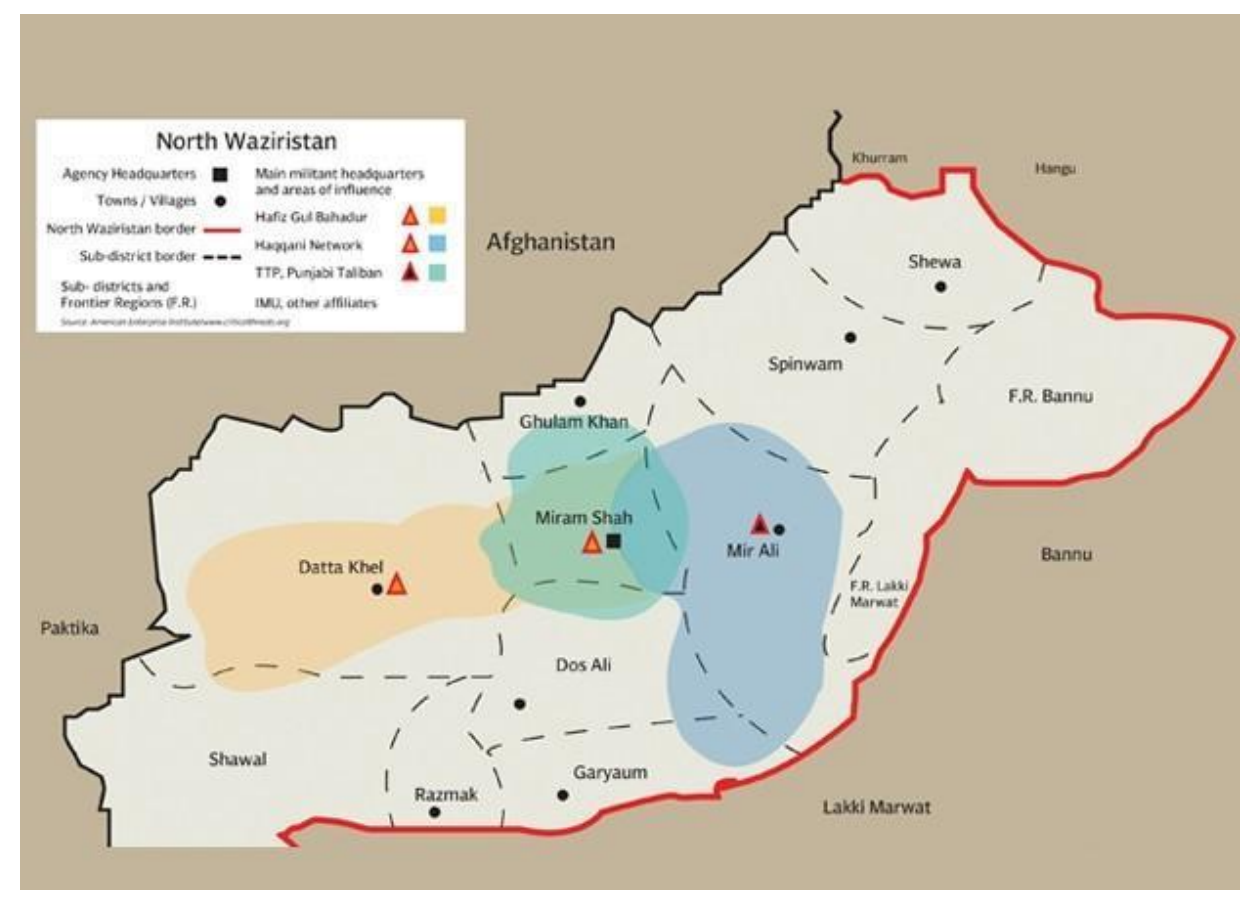

Figure 2. Map of Zarb E Azb

"We are living on absolutely destroyed land," lamented Talibdeen, a Machas village resident. "My children are weeping and they are homesick. We lack access to safe drinking water and basic infrastructure such as clinics, hospitals, and medicinal dispensaries. They offered us two tents upon our return "he explained to VOA. "We built a wall around the field where our house once stood using our own fabric and wood beams, but when the weather is bad, the cloth breaks away and our women try to stitch it back together." The settlement, located near the district capital of North Waziristan, Miranshah, is just 11 miles from Afghanistan's southeastern frontier. Residents told VOA they lack access to essential utilities such as potable water and electricity considering their proximity to the district center. Local residents have been awaiting the government's reconstruction of the town and compensation for their houses.

\subsubsection{Half-a-million people displaced}

According to the United Nations Human Rights Council (UNHCR), about 500,000 civilians left their homes in the region during Pakistani military operations. According to some locals, infrastructure destruction sustained by operations and drone strikes against insurgent organizations has made many of their homes uninhabitable. Pakistan's government declared relief for those affected by the war in 2014, under the leadership of then-Prime Minister Nawaz Sharif. Per returnee, household received a stipend of 25,000 Pakistani Rupees (\$250 USD), a transportation allowance of 10,000 Pakistani Rupees ( $\$ 100$ USD), and up to 400,000 Pakistani Rupees $(\$ 4,000$ USD) in restoration assistance, depending on the extent of harm to their houses.

The Provincial Disaster Management Authority (PDMA) of Khyber Pakhtunkhwa, a federal government agency tasked with responding to natural and man-made disasters, informed VOA that 15,222 internally displaced families are still expected to return to their villages in North Waziristan. Ihsan Dawar, a PDMA spokesperson, said current internally displaced persons (IDPs) earn 12,000 rupees per month per household. Those returning to their village are compensated with a return grant, transportation allowance, essential amenities, and a food ration for up to six months as the Pakistani government completes the damage evaluation report in order to determine final reimbursement. "The PDMA is solely tasked with emergency relief "Dawar explained to VOA. "The municipal government is responsible for conducting assessments to determine the extent of property loss. The PDMA can compensate individuals only if the local government approves them via their survey reports."

Many locals say they have been waiting months in vain for the municipal authority to conduct an assessment of their destroyed properties. They would have to depend on their own meager resources for months to come as winter approaches due to the sluggish speed of rebuilding and shortage of facilities. "The government assured us that within a week of our departure, officials conducted a survey to ascertain our needs. It's been nearly six months and not a single government official has come to conduct a survey of the city," said Noor Adam Khan, an IDP Committee member, and Machas resident. "Our children may not have access to sanitation or classrooms. They became illiterate to the point of becoming illiterate!" Khan explained to VOA. "We are without energy, and it is very humid. We lack medicinal dispensaries, which means that if our children get ill, they are at the hands of God. The government made these commitments to us but has not kept them." 


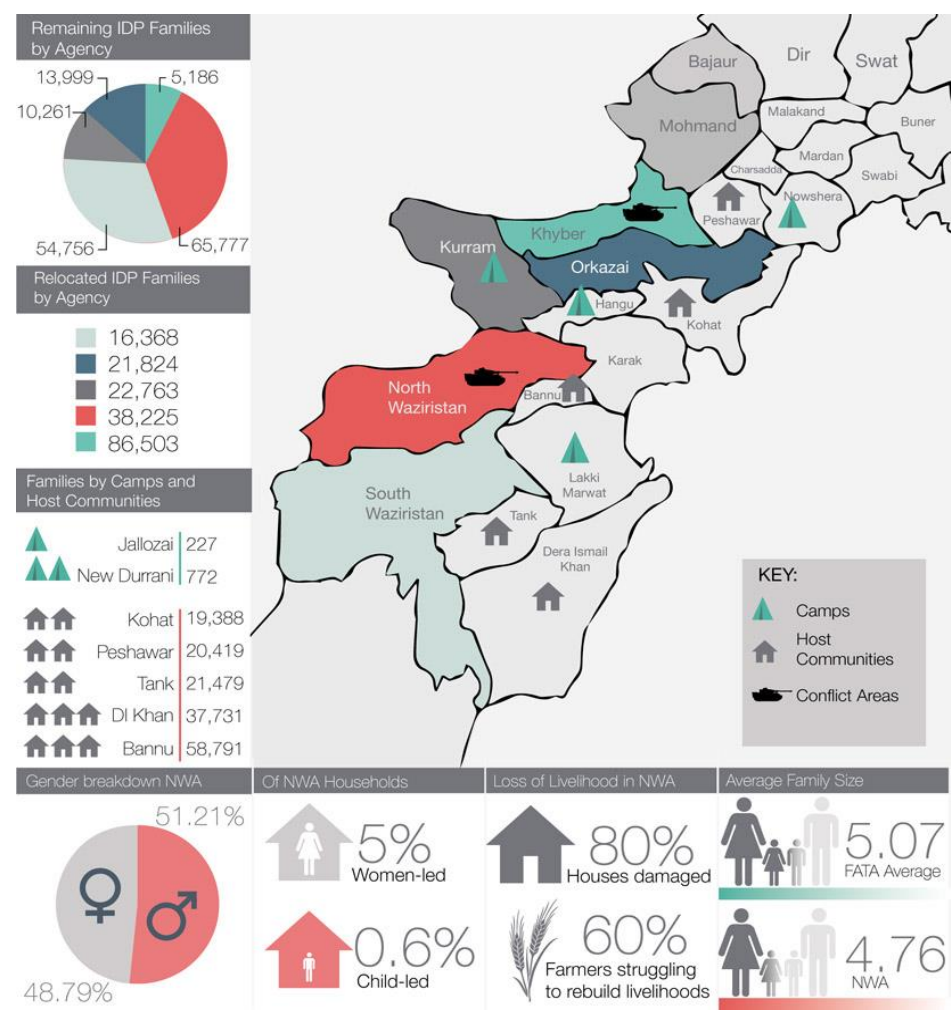

Figure 3. Zarb e Azb War Zone Stats

On the other hand, local authorities say that surveys are almost complete, with the exception of Machas owing to the spread of coronavirus. "The majority of regions have been assessed. Machas village survey could not be conducted owing to the survey being closed in March 2020 due to COVID-19," the office of the deputy commissioner of North Waziristan told VOA, adding that surveying will restart "shortly.""

According to some Pakistani analysts, previous attempts to redevelop the city have been hampered by corruption and misappropriation of funds by some local officials. Shuja Nawaz, a South Asian political analyst and former head of the Atlantic Council's South Asia Center in Washington, told VOA that potential reconstruction progress in the former Federally Administered Tribal Areas (FATA) is dependent on local authorities providing outlets to beneficiaries without leakage. "From 2002 to 2018, Pakistan obtained $\$ 8.3$ billion in security assistance from the US and an extra $\$ 14.6$ billion for relocating their military and conducting operations in FATA," Nawaz added, adding that Pakistan says the expense of combating terrorism in the district was significantly higher than previously reported. North Waziristan was incorporated into Khyber Pakhtunkhwa province in 2018 after the unification of the Federally Administered Tribal Areas (FATA). According to the FATA Research Center, a nonpartisan Pakistani organization, North Waziristan alone experienced 102 terrorism-related events between 2018 and 2019, resulting in 110 deaths.

Local media outlets in the area have confirmed an increase in civilian targeted killings this year, including beheadings and attacks on security forces by "unidentified gunmen." According to some analysts, increased terrorist violence and the government's ongoing inability to provide basic services could expose additional civilians to infiltration by insurgent groups. According to Michael Kugelman, deputy director of the Asia Program and Senior Associate for South Asia at the Wilson Center, North Waziristan was historically "ground zero" for both domestic and foreign terrorist organizations. While the Pakistani military's 2014 counterterrorism operation degraded some insurgent organizations, others deemed less dangerous to Islamabad continue to seek refuge in the region, Kugelman said. "It's also worth noting that the Pakistanis targeted groups like the [TPP] that attack the Pakistani state, rather than those like the Haqqani network that are used as state assets to advance Pakistan's interests and are located in Pakistan but conduct attacks outside the country," he said.

\section{CONCLUSION}

Although the civil war has ended, Sri Lanka's overall situation has just recently started to improve. A sizable number of Tamils also been in exile. While the number of political and human rights violations has decreased, the severity of enforced disappearances and torture has increased. Additionally, the Sri Lankan government conducts routine surveys and surveillance of individuals affiliated with the LTTE. The military continues to play a part in the majority of Sri Lanka's Tamil districts, albeit in significantly reduced numbers compared to prior to the civil war. Predominantly antiTamil is the government's Prevention of Terrorism Act (PTA). Indirectly, the Sri Lankan government is rising the political disenfranchisement of the Tamil people. For e.g., because of "Sinhalaization," the Tamil community has found it more challenging to preserve their Sinhalese language. Sinhalese temples, road signs, towns, villages, and Buddhist monuments acquired popularity in Tamil regions. Additionally, these attempts wiped out the Tamil view on Sri Lankan history and community. 
Race might have been a point of contention prior to devolution, but it was not the source of contention. The subsequent period could be different. At the conclusion of the civil war, the government has often been a source of resentment for Tamils. Following the civil war, the government's policies against Tamils and Sinhalese have become more punitive. The administration's aggressive usage of extraordinary political force in reaction to Black Lives Matter demonstrations demonstrated the administration's ability to act against popular will. Sri Lanka's regime started to rise during the country's civil war, which was precipitated by the island's centuries-old British colonial influence. The government has been steadily increasing its power for several years. Finally, it is unclear what this suggests for Sri Lanka's future. And, even though the country's racial wounds from the Sri Lankan civil war and political tensions can be healed, the nation will continue to face more serious problems about its heritage and leadership. On the other hand, safe citizenship would serve as a formidable check on a government's might. Unification of the islands might very well be the path to a more stable future. Sri Lanka is now one of Asia's most famous tourist destinations. Sri Lanka's tourism industry has exploded in growth after the war ended. Additionally, it is recognized as a prosperous country that is favorable to international sports. Sri Lanka and India jointly played the 2011 cricket world cup. To recap, after decades of turmoil and civil wars, Sri Lanka eventually enjoys peace and growth. Pakistani authorities reported 929,859 displaced civilians (from 80,302 families) as a result of the campaign on 14 July. Financial assistance, relief supplies, and food packages were distributed, and the army created 59 donation points throughout Pakistan.

On 10 July, Pakistan's Foreign Office affirmed that the resettlement of internally displaced people was a domestic matter and that Pakistan had not sought international assistance. "We have received very specific orders from the prime minister [not to demand foreign assistance], and Pakistan has made no appeal for international assistance and has no intention of doing so. It has been made abundantly clear that all costs associated with temporarily displaced Pakistanis will be borne out of our own funds ", according to Pakistani Foreign Office spokesman Tasnim Aslam. The US, however, provided \$31 million for IDPs and an extra \$9.3 million for health, hygiene, water, and sanitation for IDPs and livestock. Additionally, the United Arab Emirates government contributed \$20.5 million in humanitarian assistance to IDPs. Pakistani Finance Minister Ishaq Dar told visiting US Senator Jack Reed in February 2014 that the operation's expense had hit Rs40 billion (US\$250 million) and could cross Rs130 billion (US\$810 million).

\section{The Contribution OF THE STUdy}

Pakistan's military adopted a military policy named "Seek, Destroy, Clear, Hold" for the first time. Pakistan's military would search out the assailant. It would be lost until discovered. When the infrastructure, bodies, and arms are lost, the region will be held both before and after the mission is complete to maintain post-operation stability, infrastructure reconstruction, and/or area recovery. The Seek and Destroy component dates back to the Vietnam War, while the Clear and Keep component dates back to the Iraq War. To ensure the operation's effectiveness, the Pakistani military fused the two ideologies into a single doctrine.

One and a half years after the launch of Zarb-e-Azb, incredible progress was made, with the final pockets near the Pakistan-Afghan border being cleared. The terrorists' foundation has been severed and their structure destroyed. The nexus with sleeper cells has been significantly broken. The residual sleeper cells were neutralized by intelligence-based operations (IBOs). 3,400 terrorists were killed, and 837 terrorist hideouts were demolished. Over the last 18 months, over 13,200 IBOs have been carried out throughout the world, resulting in the death of 183 terrorists and the detention of 2,193. IBOs appear to occur. In Operation Zarb-e-Azb, 488 officers and men of the Pakistan Army, Frontier Corps KPK, Baluchistan, and Rangers Sindh were killed and 1,914 were wounded. Eleven combat courts in all. There have been 142 referrals to military commissions. 55 appeals have been settled, while 87 are already pending. Thirty-one terrorists arrested. General Raheel Sharif, Pakistan's Army Chief, toured the military's forward-most positions along the Afghan border in North Waziristan in July. He was updated on the status of Operation Zarb-e-Azb and potential plans. Sharif often paid visits to the agencies of South Waziristan and Wana. According to reports, Pakistan's military had recently concluded tentative arrangements for the final process. Peaks were cleared in the region around Shawal.

\section{REFERENCES}

Ahmad, U. (2018). The Evolution of the Role of the Objectives Resolution in the Constitutional Paradigm of Pakistan: From the Framers' Intent to a Tool for Judicial Overreach. Lahore University of Management Sciences Law Journal, 5(1), 50-60.

Army chief celebrates Eid with troops, IDPs". Dawn. 1 August 2014. Retrieved 14 August 2014.

Belokrenitsky, V. I., \& Moskalenko, V. N. (2013). A Political History of Pakistan, 1947-2007. Oxford University Press, Pakistan.

Choudhry, S. A. (2012). Constitutional History of Pakistan. PLD Publishers. Lahore, Pakistan.

Choudhury, G. W. (1969). Constitutional Development in Pakistan. Longman, London, UK.

Command and control system of terrorists destroyed in NW: Khawaja Asif". The Express Tribune. 19 July 2014. Archived from the original on 20 July 2014. Retrieved 20 July 2014.

Dexter Filkins and Waruna Karunatilake, "Sri Lankan President Wounded in Suicide Bomber Attack," The Los Angeles Times, December 19, 1999.

DeVotta, "The Liberation Tigers of Tamil Eelam and the Lost Quest for Separatism in Sri Lanka," 1042.

David Little, Sri Lanka: The Invention of Enmity (Washington, D.C.: United States Institute of Peace, 1994), 54-55.

Forty-eight suspected militants killed in fresh NWA, Khyber airstrikes". Zahir Shah Sherazi. Dawn. 19 August 2014. Retrieved 19 August 2014

Francis Fukuyama, "The Last English Civil War," Dædalus 147 (1) (Winter 2018). 
Gunnar Sørbø, Jonathan Goodhand, Bart Klem, et al., Pawns of Peace: Evaluation of Norwegian Peace Efforts in Sri Lanka, $1997-$ 2009 (Oslo: Norwegian Agency for Development Cooperation, 2011), 33-34.

Harris, "War Termination in Sri Lanka," 72

Hali, S. M. (2010). Liaquat Ali Khan-An Unheralded Founding Father of Pakistan. Criterion, Rawalpindi, Pakistan, 5(1), $132-169$.

Hayat, S. (1991). Aspects of the Pakistan Movement. National Institute of Historical and Cultural Research, Center of Excellence, Quaid-e-Azam University, Islamabad, Pakistan.

Hasan, K. S. (1951). The Foreign Policy of Mr. Liaquat Ali Khan. Pakistan Horizon, 4(4), 181-199.

James D. Fearon, "Civil War \& the Current International System," Dædalus 146 (4) (Fall 2017)

Jets flatten six hideouts, killing 30 terrorists". The Express Tribune. 6 August 2014. Retrieved 14 August 2014.

Khan, H. (2005). Constitutional and Political History of Pakistan. Oxford University Press, USA.

Kundi, M. A. (2009). US Pakistan's relations under Khan 1958-69: Impact on South Asia. A Research Journal of South Asian Studies, 24(2), 192-203.

Kazimi, M. R. (2003). Liaquat Ali Khan: his life and work. Oxford University Press, USA.

Lau, M. (2006). The Role of Islam in the Legal System of Pakistan (Chapter 3: Article 2A and the Objectives Resolution). LondonLeiden Series on Law, Administration and Development. Brill Nijhoff. Leiden, Netherlands.

Lewis, S. R. (1969). Economic Policy and Industrial Growth in Pakistan. Allen \& Unwin, London, UK.

Matthew Weaver and Gethin Chamberlain, "Sri Lanka Declares End to the Tamil Tigers," The Guardian, May 19, 2009.

M. R. Narayan Swamy, Tigers of Lanka: From Boys to Guerillas (New Delhi: Konark Publishers, 1995), 49-92.

Mukhtar, S. (2019) Social Transformation of Pakistan under Kashmir Dispute. Social Transformation in Contemporary Society, Lithuania. Mykolas Romeris University, 7, 36-45.

Mukhtar, S. (2017). Social Transformation of Pakistan under the Objectives Resolution. Social Transformation in Contemporary Society. Lithuania. Mykolas Romeris University, 5, 67-77.

Mukhtar, S. (2016). Social Transformation of Pakistan under the Constitution of 1973. Social Transformations in Contemporary Society. Lithuania. Mykolas Romeris University, 4, 47-59.

Morgeson, F. P., \& Ilies, R. (2007). Correlations between leadership traits and leadership styles. Unpublished raw data. Michigan State University, East Lansing, MI.

Mumford, M. D., Zaccaro, S. J., Harding, F. D., Fleishman, E. A., \& Reiter-Palmon, R. (1993). Cognitive and temperament predictors of executive ability: Principles for developing leadership capacity. Alexandria, VA: U.S. Army Research Institute for the Behavioral and Social Sciences.

Mumford, M. D., Zaccaro, S. J., Harding, F. D., Jacobs, T. O., \& Fleishman, E. A. (2000). Leadership skills for a changing world: Solving complex social problems. The Leadership Quarterly, 11(1), 11-35.

Muhammad, Ahmad, Tragedy Of Benazir Bhutto (1953-2007).

Neil DeVotta, "The Liberation Tigers of Tamil Eelam and the Lost Quest for Separatism in Sri Lanka," Asian Survey 49 (6) (2009): $1021-1051$.

Nawaz expresses confidence over PTI dialogue during National Security Conference". The Express Tribune. 9 August 2014. Archived from the original on 11 August 2014. Retrieved 14 August 2014.

Operation Zarb-e-Azb continues, 2 soldiers and 7 Uzbek militants killed in clash". The Asian Time. 4 August 2014. Retrieved 14 August 2014

Paul S. (1962). Islam and the Constitution of Pakistan. World Affairs. 125 (2), 92-96.

Press Releases of 16 July". ISPR. 16 July 2014. Archived from the original on 17 July 2014. Retrieved 17 July 2014.

Press Releases of 19 July". ISPR. Archived from the original on 20 July 2014. Retrieved 20 July 2014.

Raza, S. S. (2017). Contested Space of the Objectives Resolution in the Constitutional Order of Pakistan. Islamabad Policy Research Institute Journal. 17(2), 1-19.

Rahman. F. (1973). Islam and the New Constitution of Pakistan. Journal of Asian and African Studies. 8(3), 190-204.

Rahman. F. (1970). Islam and the Constitutional Problem of Pakistan. Studia Islamica. 32(2), 275-287.

Rockets fired into security forces camp in Miramshah". The Express Tribune. 14 August 2014. Archived from the original on 14 August 2014. Retrieved 14 August 2014.

Shah, N. H. (1987). The Objectives Resolution and its Impact on the Administration of Justice in Pakistan. Islamic Studies, 26(4), 38339

Saroja Selvanathan and Eliyathamby A. Selvanathan, "Defence Expenditures and Economic Growth: A Case Study of Sri Lanka Using Causal Analysis," International Journal of Development Studies 4 (2) (2014): 69-76.

Seven Uzbek militants and two soldiers killed in FATA". South Asia Terrorism Portal. Retrieved 14 August 2014.

Shabbir, T., M Nadeemullah, \& Saeed Memon. (2020). Uses and Impact of 'Open Data' Technology for Developing Social Sector in Pakistan. Pakistan Journal of Multidisciplinary Research, 1(1), 50-64. Retrieved from https://www.pjmr.org/pjmr/article/view/24

Schofield, Victoria. Bhutto: Trial and Execution. London: Chassell, 1979. also see http://www.victoriaschofield.com/info8.htm

Syed, Anwar H. Pakistan: Islam, Politics and National Solidarity. Lahore: Awami Press, $1984 . \quad$ also see http://rac.sagepub.com/content/28/3/41.full.pdf

Syed, Anwar H. The Discourse and Politic of Zulfiqar Ali Bhutto. London: Macmillan, 1992. . http://www.jstor.org also see http://ebookstorm.com/ebook/4282939/discourse-and-politics-of-zulfikar-ali-bhutto

Schriesheim, C. A. and Kerr, S. (1977a) "Theories and Measures of Leadership," in J.G. Hunt, and L.L. Larson (eds), Leadership: The Cutting Edge, Carbondale, IL: Southern Illinois University Press, 9-45. 
Three terrorists killed in operation in Mir Ali". Radio Pakistan. 2 August 2014. Retrieved 14 August 2014.

Twenty terrorists killed in air strikes". Radio Pakistan. 23 July 2014. Archived from the original on 23 July 2014. Retrieved 23 July 2014.

Two soldiers killed in IED blast on Pakistan-Afghanistan border". The Express Tribune. 24 July 2014. Archived from the original on 24 July 2014. Retrieved 24 July 2014.

Wolpert, S. A. (1984). Jinnah of Pakistan. Oxford University Press, USA.

Zaidi, S. M. Z. (2010). The Assassination of the Prime Minister Liaquat Ali Khan: the fateful journey. Pakistan Journal of History and Culture, 31(1), 72-100.

Zarb-e-Azb: 28 terrorists killed in Shawal air strikes". The News. 20 July 2014. Archived from the original on 20 July 2014. Retrieved 20 July 2014.

Zarb-e-Azb: Eight militants killed and five hideouts destroyed". The Nation. 26 July 2014. Archived from the original on 26 July 2014. Retrieved 26 July 2014.

Zarb-i-Azb: Army claims 70pc area of Mirali cleared in NWA". Dawn. 27 July 2014. Archived from the original on 27 July 2014. Retrieved 27 July 2014. 